\title{
Chemical Composition and Cytotoxic Activities of Petroleum Ether Fruit Extract of Fruits of Brucea javanica (Simarubaceae)
}

\author{
Zhiwei Su ${ }^{1,2}$, Huijuan Huang ${ }^{3}$, Jinlian $\mathrm{Li}^{1,4}$, Yuehui Zhu ${ }^{1}$, Riming Huang ${ }^{1}$ and \\ Samuel X Qiu ${ }^{1^{*}}$ \\ ${ }^{1}$ Program for Natural Product Medicinal Chemistry and Drug Discovery, Key Laboratory of Plant Resources Conservation and \\ Sustainable Utilization, South China Botanical Garden, Chinese Academy of Sciences, Guangzhou 510650, ${ }^{2}$ University of \\ Chinese Academy of Sciences, Beijing 100049, ${ }^{3}$ Guangdong provincial Key Lab of Biotechnology for Plant Development, South \\ China Normal University, Guangzhou 510631, ${ }^{4}$ Chinese Academy of Science - Foshan Biotech and Pharmaceutical Center, \\ Foshan 528231, People's Republic of China.
}

*For correspondence: Email: sxqiu@scbg.ac.cn; Tel.: +86 203708 1190; Fax: +86 2037081190

\begin{abstract}
Purpose: To investigate the chemical composition and antitumor activity of the petroleum ether extract of the dried ripe fruits of Brucea javanica.

Methods: The composition of petroleum ether extract was analyzed by gas chromatography/mass spectrometric (GC/MS) and their antitumor activities were determined by MTT assay.

Results: GC/MS spectrometry results indicate that the petroleum ether extract was a mixture of esters, fatty acids, sterides, pregnanones, terpenes, alkaloids, alkenes, alcohols, ketones, aldehydes and other compounds. The results also revealed the significant antitumor activity of the extract with $I C_{50}$ of $9.14,12.45$, 15.15, 16.13, 22.26, and 27.97 $\mathrm{gg} / \mathrm{mL}$ against A549, CNE, MCF-7, NCI-H460, HepG2, and KB-3-1 cell lines, respectively.

Conclusion: The study establishes the chemical composition and cytotoxic activity of the petroleum ether extract of the plant fruits. There is need for further investigations to isolate more potent compounds and structurally modify the known compounds to retain activity and lower toxicity and thus lead to the possible development of Brucea javanica oil.
\end{abstract}

Keywords: Brucae javanica, Mass spectra, Cytotoxic activity, Anti-tumour.

Tropical Journal of Pharmaceutical Research is indexed by Science Citation Index (SciSearch), Scopus, International Pharmaceutical Abstract, Chemical Abstracts, Embase, Index Copernicus, EBSCO, African Index Medicus, JournalSeek, Journal Citation Reports/Science Edition, Directory of Open Access Journals (DOAJ), African Journal Online, Bioline International, Open-J-Gate and Pharmacy Abstracts

\section{INTRODUCTION}

Natural products have long been an abundant source of therapeutic agents [1]. Recently, much attention has been paid to the Brucea genus and its chemical constituents because of its manysided activities. Many chemical constituents have been isolated from Brucea genus, including quassinoids, alkaloids, triterpenoids, and flavonoids [2-5]. Its core components are quassinoids, which possess various biological activities including anti-tumor [4], anti-malarial and anti-babesial [6,7], anti-viral [8], anti-bacterial $[9,10]$ and hyperglycemic $[11]$ activities.

Brucea. javanica (L.) Merr., a Chinese herbal medicine called 'Yadanzi', is distributed in south of China (mainly in Guangxi and Guangdong Provinces) and shows significant antitumor and other activities mostly due to quassinoids, triterpenoids and alkaloids [12]. Recent research has focused on the constituents of the ethyl 
acetate and n-butanol extracts of $B$. javanica. Brucea javanica oil (BJO) is a petroleum ether extract is mainly composed of fatty acids and fatty acid derivatives, which were extracted with petroleum ether from the fruits of $B$. javanica [13]. It has been used as anti-tumor agent to therapy hepatic, esophageal, rectal, pulmonic, renal, and prostatic carcinomas clinically [14]. However, the petroleum ether-soluble compositions of $B$. javanica seldom got attention, which is not conducive to the use of BJO on therapy. As a continuation of our search for naturally occurring bioactive substances from herb medicine in China, we investigated the constituents of the fruits from $B$. javanica.

Our objectives in the present work were, first, to determine the petroleum ether chemical compositions of $B$. javanica by GC/MS analysis and, second, to evaluate the antitumor efficacy of the crude extract and its petroleum ether fractions.

\section{EXPERIMENTAL}

\section{Plant material}

The air-dried fruits of $B$. javanica were purchased from Qingping Local Medicine Market at Guangzhou, China, in January 2008, identified by Prof. Yun-fei DENG of SCBG (South China Botanical Garden, Chinese Academy of Sciences) and a voucher specimen (no. $\mathrm{MZH0173)}$ has been deposited in the herbarium of SCBG.

\section{Extraction and separation}

The air-dried fruits $(10 \mathrm{~kg})$ were ground and extracted three times by maceration with $95 \%$ ethanol at room temperature. After filtration, the extract was concentrated in vacuum at $40{ }^{\circ} \mathrm{C}$ to yield $2 \mathrm{~L}$ viscous liquid. The crude ethanol extract was suspended in warm distilled water $(100 \mathrm{~mL})$ to afford an aqueous ethanol solution (95\%), then partitioned exhaustively with petroleum ether $(3 \times 2500 \mathrm{~mL})$, followed by ethyl acetate ( 3 $\times 2500 \mathrm{~mL})$, and $\mathrm{n}$-butanol ( $3 \times 2500 \mathrm{~mL})$, to aff ord petroleum ester- $(400 \mathrm{~mL})$, ethyl acetate(800 mL), n-butanol- (500 mL) and H2O-soluble viscous extracts respectively.

The petroleum ether-soluble extract was subjected to silica gel $(80-100 \mathrm{~A}, 400 \mathrm{~g})$ column chromatography, and eluted with gradient mixtures of $\mathrm{CHCl}_{3}-\mathrm{MeOH}$ (from 1:0 to $0: 1$ ) to afford 300 fractions (250 mL each). Eight major subfractions (Fr1 - 8) were obtained by pooling fractions with similar TLC patterns. Each fraction (1 $\mathrm{mg}$ ) was dissolved in and diluted to $1 \mathrm{~mL}$ distilled dichloromethane, which was identified by GC/MS analysis separately.

\section{GC/MS conditions}

GC/MS analysis was performed on Agilent AOC20S Gas Chromatograph Mass Spectrometer. A petroleum ether phenomenex HP-5 fused silica column $(30 \mathrm{~m} \times 0.25 \mathrm{~mm} \times 0.25 \mu \mathrm{m})$ was used with helium at a linear velocity of $36.8 \mathrm{~cm} / \mathrm{sec}$ (65.2 psi) as a carrier gas. The GC oven temperature was programmed from $80{ }^{\circ} \mathrm{C}$, increasing at $2{ }^{\circ} \mathrm{C} / \mathrm{min}$, up to $150{ }^{\circ} \mathrm{C}$ with a $2 \mathrm{~min}$ hold at $150{ }^{\circ} \mathrm{C}$, then programmed from 150 to $310^{\circ} \mathrm{C}$ successively at $40^{\circ} \mathrm{C} / \mathrm{min}$ with a 2 and 20 min hold at $250{ }^{\circ} \mathrm{C}$ and $310^{\circ} \mathrm{C}$, respectively. The manual injection volume was $0.1 \mu \mathrm{L}$ and split ratio was adjusted to 1:20. The Electronic ionization was at $70 \mathrm{eV}$ and transfer line was heated at $220{ }^{\circ} \mathrm{C}$. A mass range of $10-400$ amu was scanned. This GC/MS conditions were optimized from the methods used in previous studies [15].

The identification of volatile compounds was based on the comparison of their retention times and mass spectra with those obtained from the mass spectral reference library of National Insititute of Standards and Technology as well as those found in literature.

\section{MTT cytotoxicity assay}

Human lung cancer cell line (A549), human breast carcinoma cell line (MCF-7), human hepatoma cell line (HepG2), human lung cancer cell line ( $\mathrm{NCl}-\mathrm{H} 460)$, human nasopharyngeal carcinoma cell line (CNE) and huaman epidermoid carcinoma cell line (KB-3-1) were obtained from Research Group of Pharmaceutical Sciences, Tropical Medicine Institute, Guangzhou University of Chinese Medicine, Guangzhou, China.

MTT assay, as previously described by Mosmann et al [16], was performed to assess the cytotoxicity of the plant extracts and petroleum ether fractions. Briefly, cells, grown in RPMI1640 medium plus $10 \%$ heat-inactivated foetal bovine serum, were plated in 96 well microtiter plates and incubated for $24 \mathrm{~h}$ at $37{ }^{\circ} \mathrm{C}, 5 \% \mathrm{CO}_{2}$. When cells reached $>80 \%$ confluence. The cells were treated with $100 \mu \mathrm{L}$ petroleum ether fractions dissolved in dimethyl sulfoxide (DMSO) at serial concentrations of $50,25,12.5,6.5$, 3.125 and $1.56 \mu \mathrm{g} / \mathrm{mL}$, while background wells were treated with only $100 \mu \mathrm{L}$ culture medium. 
After $72 \mathrm{~h}$ of incubation at $37^{\circ} \mathrm{C}, 5 \% \mathrm{CO}_{2}, 10 \mu \mathrm{L}$ MTT reagents $(5 \mathrm{mg} / \mathrm{mL})$ were mixed in each well and incubated at $37^{\circ} \mathrm{C}$ for a further $4 \mathrm{~h}$. Then the medium was removed and $150 \mu \mathrm{L}$ DMSO was acceded to each well after the plate was shaken thoroughly for $10 \mathrm{~min}$. The absorbance was measured on a CENios microplate reader (TECAN, Austria) at a wavelength of $570 \mathrm{~nm}$. MTT solution only with DMSO was used as blank and Doxorubicin as positive control. The half maximal inhibitory concentration $\left(\mathrm{IC}_{50}\right)$ values were calculated using SPSS software, version 16.0 , by comparison with the reduction in absorbance in the control assay.

\section{RESULTS}

\section{Chemical compositions of the petroleum ether fractions of $B$. javanica}

The identified constituents of the petroleum ether fractions of $B$. javanica and their retention indices (RI) values, percentage composition are presented in Table 1. A total of 151 components were identified from these fractions. They were found to be a mixture of esters, fatty acids, alkenes, alcohols, ketones, aldehydes, terpenes, pregnanones, steroids, alkaloids and other compounds.

Table 1(a): Chemical constituents of petroleum ether fractions (Fr1-8) of B. javanica

\begin{tabular}{|c|c|c|c|c|c|}
\hline Compound & $\mathbf{R I}$ & Fr / content ( $\%)$ & Compound & $\mathbf{R I}$ & Fr / content (\%) \\
\hline \multicolumn{6}{|l|}{ Esters } \\
\hline $\begin{array}{l}\text { 2-Ethyl-n-butyric acid ethyl } \\
\text { ester }\end{array}$ & 920 & Fr6 / 2.21 & Ethyl hexadecanoate & 1978 & Fr1 / 8.62 \\
\hline $\begin{array}{l}\text { Butanedioic acid, monomethyl } \\
\text { ester }\end{array}$ & 1042 & Fr7 / 0.77 & $\begin{array}{l}\text { Methyl 2- } \\
\text { hydroxyhexadecanoate }\end{array}$ & 2041 & Fr3 / 5.36 \\
\hline $\begin{array}{l}\text { Pentanedioic acid, } \\
\text { monomethyl ester }\end{array}$ & 1141 & Fr6 / 0.33 & $\begin{array}{l}\text { n-Octadecanoic acid methyl } \\
\text { ester }\end{array}$ & 2077 & Fr1 / 7.48 \\
\hline trans-2-Hexenyl Butyrate & 1191 & $\mathrm{Fr} 2 / 0.26$ & $\begin{array}{l}\text { (Z)-9-octadecenoic acid methyl } \\
\text { ester }\end{array}$ & 2085 & $\begin{array}{l}\text { Fr1,2,5,7 / 30.15, } \\
1.97,1.23,1.37\end{array}$ \\
\hline $\begin{array}{l}\text { 3-Hydroxy-2-methylglutaric } \\
\text { acid dimethyl ester }\end{array}$ & 1249 & Fr5 / 0.63 & $\begin{array}{l}\text { Methyl cis, cis-9,12- } \\
\text { octadecadienoate }\end{array}$ & 2093 & $\begin{array}{l}\text { Fr1,2,3 / } 4.67 \\
1.72,0.53\end{array}$ \\
\hline Methyl 8-hydroxyoctanoate & 1326 & Fr7 / 0.30 & $\begin{array}{l}\text { Methyl cis-9,10- } \\
\text { epoxyoctadecanoate }\end{array}$ & 2129 & Fr4 / 13.28 \\
\hline Monon & 1340 & Fr6 / 0.40 & Ethyl n-octadecanoate & 2177 & $\mathrm{Fr}$ \\
\hline ledioate & 1350 & Fr3,6 / 0.62, 0.36 & $\begin{array}{l}\text { (Z)-9-Octadecenoic acid ethyl } \\
\text { ester }\end{array}$ & 2185 & 15.56 \\
\hline $\begin{array}{l}\text { 9-oxo-Nonanoic acid methyl } \\
\text { ester }\end{array}$ & 1371 & $\begin{array}{l}\text { Fr3,4,7 / 1.45, } \\
0.90,0.21\end{array}$ & $\begin{array}{l}\text { Ethyl cis, cis-9,12- } \\
\text { octadecadienoate }\end{array}$ & 2193 & Fr1 / 3.11 \\
\hline $\begin{array}{l}\text { 4-hydroxy-Benzeneacetic acid } \\
\text { methyl ester }\end{array}$ & 1380 & Fr4 / 0.95 & $\begin{array}{l}\text { 2-[(2-nonylcyclopropyl)methyl]- } \\
\text { Cyclopropanebutyric acid, } \\
\text { methyl ester }\end{array}$ & 2203 & Fr4 / 3.84 \\
\hline Ethyl $d$ & 1381 & Fr1/ & Methyl 7-hydroxystearate & 2239 & Fr4 / 1.00 \\
\hline anoate & 1425 & Fr6 / 0.62 & acid methyl ester & 2276 & Fr1 / 0.97 \\
\hline nonanedioate & 1449 & $\begin{array}{l}\text { Fr3,5,6 / 4.4, } \\
9.46,2.06\end{array}$ & Methyl-(11E)-icosenoate & 2284 & Fr1 / 0.61 \\
\hline $\begin{array}{l}\text { 4-hydroxy-Benzeneacetic acid } \\
\text { ethyl ester }\end{array}$ & 1480 & Fr4 / 0.36 & Eicosanoic acid ethyl ester & 2375 & $\mathrm{Fr1} / 0.31$ \\
\hline Dodecanoic acid methyl ester & 1481 & Fr1 / 0.06 & $\begin{array}{l}\text { 10- } \\
\text { octadecanoate }\end{array}$ & 2402 & $\begin{array}{l}\text { Fr3 } 3,4,7 / 2.78 \\
7.88,47.59\end{array}$ \\
\hline Dodecanoic acid ethenyl ester & 1570 & Fr6 & Docosanoic acid methyl ester & 2475 & Fr1 / 0.58 \\
\hline Methy & 1680 & & $\begin{array}{l}\text { Hexadecanoic acid, 2-hydroxy- } \\
1 \text { - } \\
\text { (hydroxymethyl) ethyl ester }\end{array}$ & 2498 & Fr8 / 8.87 \\
\hline Ethyl myristate & 1779 & Fr1 / 0.13 & $\begin{array}{l}\text { 8,11,14-Docosatrienoic acid, } \\
\text { methyl ester }\end{array}$ & 2499 & $\begin{array}{l}\mathrm{Fr} 2,4 / 1.24 \\
5.56\end{array}$ \\
\hline Methyl n-pentadecanoate & 1779 & Fr1 / 0.29 & $\begin{array}{l}\text { Tetracosanoic acid, methyl } \\
\text { ester }\end{array}$ & 2674 & Fr1 / 0.42 \\
\hline $\begin{array}{l}\text { 2-Phenylethyl } \\
\text { cyclohexanecarboxylate }\end{array}$ & 1820 & Fr6 / 4.65 & Ethyl iso-allocholate & 3094 & Fr3 / 1.74 \\
\hline $\begin{array}{l}\text { n-Hexadecanoic acid methyl } \\
\text { ester }\end{array}$ & 1878 & Fr1 / 22.89 & $\begin{array}{l}\text { 1-O-Hexadecanoyl-3-O- } \\
\text { (9Z-octadecenoyl) glycerol }\end{array}$ & 4204 & Fr5 / 20.82 \\
\hline $\begin{array}{l}\text { (Z)-7-Hexadecenoic acid } \\
\text { methyl ester }\end{array}$ & 1886 & $\begin{array}{l}\text { Fr1 } 1,4,7 / 0.11 \\
1.59,6.79\end{array}$ & $\begin{array}{l}\text { 2,3-Bis }[(9 E)-9- \\
\text { octadecenoyloxy] }\end{array}$ & 6149 & $\begin{array}{l}\text { Fr4,5,6,7,8/3.38, } \\
15.62,12.44\end{array}$ \\
\hline $\begin{array}{l}\text { Methyl 15- } \\
\text { methylhexadecanoate }\end{array}$ & 1914 & Fr1 / 0.76 & propyl(9E)-9-octadecenoate & & $4.02,70.29$ \\
\hline
\end{tabular}


Table 1(b): Chemical constituents of petroleum ether fractions (Fr1-8) of B. javanica (contd)

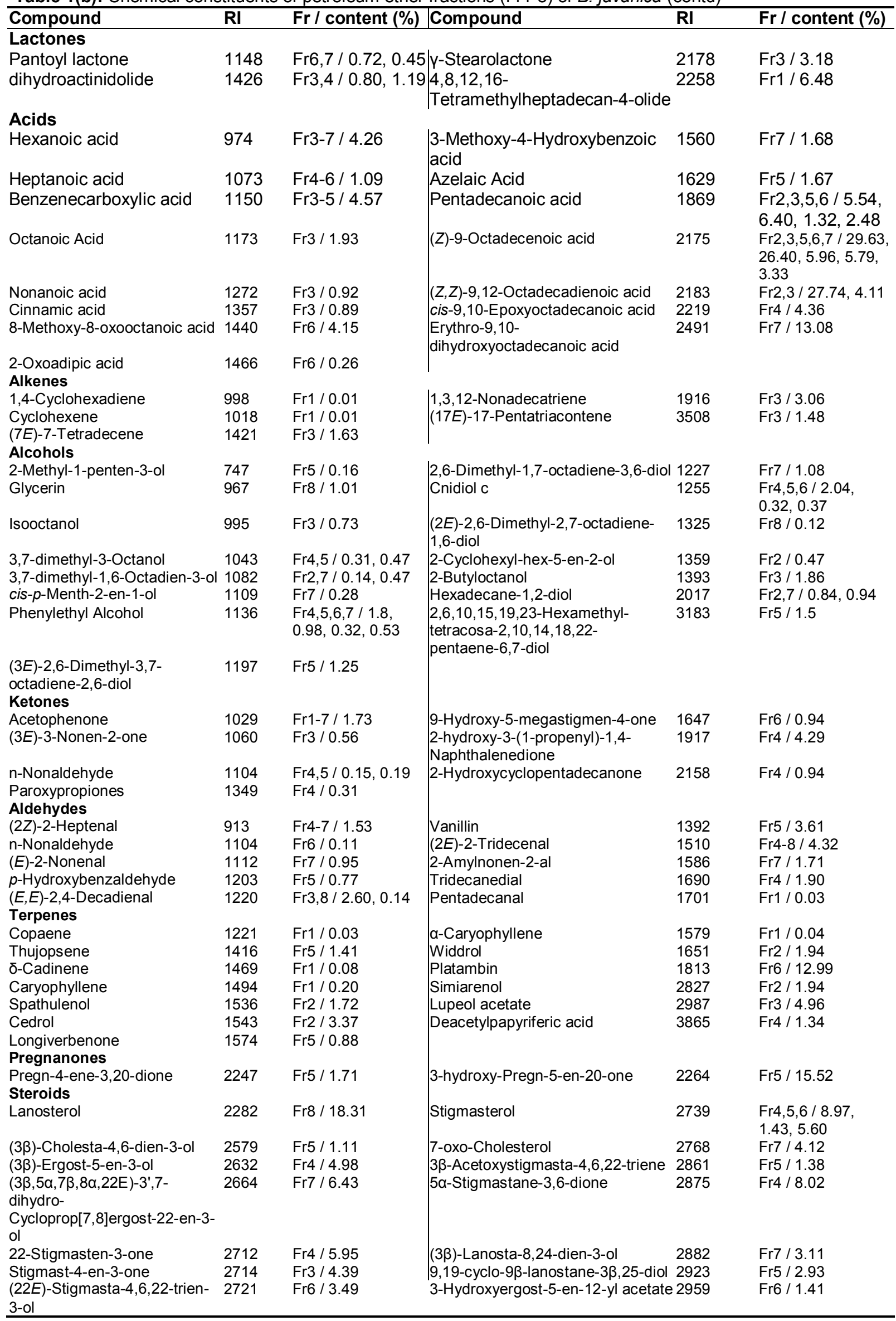


Table 1(d): Chemical constituents of petroleum ether fractions (Fr1 - 8) of B. javanica (contd)

\begin{tabular}{|c|c|c|c|c|c|}
\hline Compound & $\mathbf{R I}$ & Fr/ content (\%) & Compound & $\mathbf{R I}$ & Fr / content (\%) \\
\hline \multicolumn{6}{|l|}{ Steroids } \\
\hline (22E)-Stigmasta-4,22-dien-3-one & 2722 & Fr3 / 2.10 & $\begin{array}{l}(3 \beta, 23 E)-3 \text {-acetate- } 9,19-C y c l o l a n o s t- \\
23 \text {-ene-3,25-diol }\end{array}$ & 3071 & Fr6 / 3.80 \\
\hline$\beta$-Sitosterol & 2731 & $\begin{array}{l}\text { Fr4,5,6 / 13.05, } \\
4.23,2.39\end{array}$ & 22,23-Dibromostigmasterol acetate & 3335 & Fr5 / 1.40 \\
\hline \multicolumn{6}{|c|}{ Alkaloids or nitrogen-containing compounds } \\
\hline Aniline & 992 & Fr5 / 0.11 & $\begin{array}{l}\mathrm{N} \text {-(3-cyclopentylpropionyl)-1- } \\
\text { Alanine methyl ester }\end{array}$ & 1760 & Fr6 / 3.66 \\
\hline 1-(1H-pyrrol-2-yl)-Ethanone & 1035 & Fr5 / 0.48 & $\begin{array}{l}\text { 4-Hydroxy-7-[2,3-dihydroxypropyl] } \\
\text { pyrrolo[2,3-d]pyrimidine }\end{array}$ & 1954 & Fr5 / 2.01 \\
\hline Methyl nicotinate & 1054 & Fr5 / 0.28 & $\begin{array}{l}\text { N-(3-cyclopentylpropionyl)-I- } \\
\text { Leucine methyl ester }\end{array}$ & 1995 & Fr7 / 1.52 \\
\hline 3-Phenylpyridine & 1361 & Fr5 / 1.72 & (Z)-9-Octadecenamide & 2228 & Fr5,8 / 1.17, 0.76 \\
\hline 3-Oxo-4-phenylbutyronitrile & 1473 & Fr4 / 0.50 & $\begin{array}{l}\text { Benzoyl-3-hydroxy-2-(3- } \\
\text { nitrophenyl)-4-imidazolidinone }\end{array}$ & 2913 & Fr5 / 6.36 \\
\hline $\begin{array}{l}\text { 2-Amino-1-(3-hydroxy-4- } \\
\text { methoxyphenyl)ethanone }\end{array}$ & 1682 & Fr4 / 0.74 & & & \\
\hline \multicolumn{6}{|l|}{ Others compounds } \\
\hline Carbon hexachloride & 995 & Fr1-7 / 0.78 & (+)-Ambraketal & 1774 & Fr3 / 1.19 \\
\hline $\begin{array}{l}\text { 4,6,10,10-Tetramethyl-5- } \\
\text { oxatricyclo[4.4.0.0(1,4)]dec-2-en-7-ol }\end{array}$ & 1457 & Fr6 / 4.32 & 13-hydroxykaur-16-en-18-oate & 2206 & Fr6 / 1.58 \\
\hline 1,2,3,5-tetraisopropyl-Cyclohexane & 1503 & Fr2 / 20.93 & $\begin{array}{l}\text { 2-(12-Pentadecynyloxy)tetrahydro- } \\
\text { 2H-pyran }\end{array}$ & 2254 & Fr6 / 1.13 \\
\hline
\end{tabular}

Note: Fr / content (\%) = the percentage content of every compound in the related fraction, for an example, Fr2 / 20.93, that means the percentage content of 1,2,3,5-tetraisopropyl-Cyclohexane in Fraction 2 is 20.93, and so on.

Fr1 was characterized by its high proportion of esters $(99.56 \%)$, of which the most abundant compounds were determined to be (Z)-9octadecenoic acid methyl ester $(30.15 \%)$, nhexadecanoic acid methyl ester (22.89\%). Fatty acids $(62.91 \%)$, others compounds $(21.05 \%)$, terpenes $(8.97 \%)$, and esters $(5.19 \%)$ predominate in $\mathrm{Fr} 2$, and consisted mainly of (Z)9-octadecenoic acid (29.63\%), (Z, Z)-9, 12octadecadienoic acid $(27.74 \%)$, and $1,2,3,5-$ tetraisopropyl-cyclohexane (20.93\%). Thirty-one components, including five repeated compounds, were found in Fr3, and consisted of fatty acids $(47.89 \%)$, esters (16.88\%), lactones $(10.46 \%)$, sterides $(6.49 \%)$, alkenes $(6.17 \%)$, terpenes $(4.96 \%)$, aldehydes $(2.6 \%)$ and alcohols $(2.59$ $\%)$. The major components of Fr3 were (Z)-9octadecenoic acid $(26.4 \%), 4,8,12,16-$ tetramethylheptadecan-4-olide $(6.48 \%)$, methyl 2-hydroxyhexadecanoate $(5.36 \%)$, lupeol acetate $(4.96 \%)$. Fr4 was marked by sterides $(40.97 \%)$, esters $(38.74 \%)$, ketones $(5.92 \%)$, fatty acids (4.86\%), alcohols (4.15\%), and aldehydes $(2.6 \%)$. The most affluent constituents were methyl cis-9, 10epoxyoctadecanoate $(13.28 \%), \quad \beta$-sitosterol (13.06 \%), stigmasterol (8.97 \%), 5a.stigmastane-3,6-dione (8.02 \%), methyl 9,10dihydroxyoctadecanoate $(7.88 \%)$, and 22stigmasten-3-one $(5.95 \%)$. The analysis of the Fr5 gave forty compounds, which were primarily 1-O-hexadecanoyl-3-O-(9Z-octadecenoyl)

glycerol (20.82 \%), vanillin (3.6\%) and thujopsene $(1.41 \%)$. Thirty-five compounds were found in Fr6 and had the main constituents as esters $(24.35 \%)$, pregnanones $(17.23 \%)$, sterides $(16.69 \%)$, terpenes $(12.99 \%)$, fatty acids $(12.94 \%)$, others $(7.20 \%)$, alkaloids (3.66 $\%)$ and aldehydes (2.39\%). The chief compounds were 3-hydroxy-pregn-5-en-20-one (15.52\%), platambin (12.99\%), 2, 3-bis [(9E)-9octadecenoyloxy] propyl (9E)-9-octadecenoate (12.44\%), (Z)-9-octadecenoic acid (5.79\%), and stigmasterol $(5.60 \%)$. Fr7 was discernible by esters $(61.05 \%)$, fatty acids $(18.31 \%)$, sterides (13.66\%), alcohols (3.30\%), and aldehydes $(2.87 \%)$. Except for the repeated constituents, the richest components were erythro-9,10dihydroxyoctadecanoic acid (13.08\%), (Z)-7hexadecenoic acid methyl ester $(6.79 \%$ and $(3 \beta, 5 \alpha, 7 \beta, 8 \alpha, 22 E)-3$ ',7-dihydro-cycloprop[7,8]er gost-22-en-3-ol (6.43\%) . Fr8 mainly contained 2, 3-bis [(9E)-9-octadecenoyloxy] propyl (9E) -9-octadecenoate $(70.29 \%)$, lanosterol (18.31\%), hexadecanoic acid, 2hydroxy-1-(hydroxymethyl) ethyl ester (8.87\%).

From our results, chemical compositions of the petroleum ether extract of $B$. javanica included $a$ high amount of esters, fatty acids and sterides. This is the first full report on the liposoluble constituents of $B$. javanica by GC/MS analysis.

\section{Cytotoxicity assay}

Six human tumor cell lines A549, MCF-7, HepG2, NCl-H460, CNE and KB-3-1 were used to investigate the in vitro antitumor effects of the different extracts and fractions of B. javanica. The $\mathrm{IC}_{50}$ values of extracts and $\mathrm{Fr} 1-8$ on the viability of cancer cells after $72 \mathrm{~h}$ of incubation are presented in Table 2. 
Table 2: Cytotoxic activities of various fractions of $B$. javanica on six cell lines

\begin{tabular}{ccccccc}
\hline \multirow{2}{*}{ Fraction } & \multicolumn{7}{c}{ IC $\mathbf{5 0}_{\mathbf{H}} \mathbf{g} / \mathbf{m L}$} \\
\cline { 2 - 7 } & $\mathbf{A 5 4 9}$ & MCF-7 & HEPG2 & NCl-460 & CNE & KB-3-1 \\
\hline Fr1 & 71.29 & $>100$ & 67.80 & - & 83.89 & $>100$ \\
Fr2 & 13.26 & 16.83 & 22.73 & - & 6.78 & 84.57 \\
Fr3 & 36.25 & 78.89 & 31.08 & - & 42.69 & 25.19 \\
Fr4 & 27.98 & 64.29 & 32.28 & - & $>100$ & $>100$ \\
Fr5 & 6.04 & 18.26 & 18.20 & 33.77 & 9.24 & 30.05 \\
Fr6 & 8.34 & 33.87 & 18.23 & 17.97 & 7.90 & 24.14 \\
Fr7 & 7.21 & 21.93 & 16.17 & 24.68 & 11.59 & 30.87 \\
Fr8 & 9.75 & 13.57 & 15.50 & 25.26 & 18.09 & 23.82 \\
BjEE & 8.79 & 15.12 & 33.31 & 19.67 & 12.81 & 21.72 \\
BjP & 9.14 & 15.15 & 22.26 & 16.13 & 12.45 & 27.97 \\
BjE & 0.02 & 3.28 & 4.14 & 5.79 & 0.48 & 9.66 \\
BjB & 17.47 & 30.92 & 27.16 & 25.75 & 24.29 & 24.08 \\
Doxorubicin & 0.16 & 2.37 & 0.52 & 0.31 & 0.37 & 0.17 \\
\hline
\end{tabular}

Note: BjEE = Ethanol Extract of Brucea javanic; BjP = Petroleum ether Extract of Brucea javanica; BjE = Ethyl acetate Extract of Brucea javanica; $B j B=n$-butyl alcohol Extract of Brucea javanica; "-" means no inhibition to tumor cell.

As shown in Table 2, the ethanol extract (BjEE) of $B$. javanica exhibited moderate cytotoxicity against all the tested cell lines with $\mathrm{IC}_{50}$ values ranging from 8.79 to $33.31 \mu \mathrm{g} / \mathrm{mL}$. Moreover, there were almost the same general tendencies of antitumor activity as to BJEE, when treated on the tested cell lines with the further petroleum ether $(B j P)$, ethyl acetate $(B j E)$ and n-butyl alcohol $(B j B)$ extracts, respectively. Among them, BJE exhibited the highest cytotoxicity with $\mathrm{IC}_{50}$ values ranging from 0.02 to $9.66 \mu \mathrm{g} / \mathrm{mL}$ against the tested tumor cell lines, followed by BJP ( 8.79 to $33.31 \mu \mathrm{g} / \mathrm{mL}$ ) and BJB (17.47 to $30.92 \mu \mathrm{g} / \mathrm{mL})$. In addition, the BjEE, BjP, BjE, BjB showed the most significant cytotoxicity against A549 cell lines with $\mathrm{IC}_{50}$ value of $8.79 \mu \mathrm{g} / \mathrm{mL}, 9.12 \mu \mathrm{g} / \mathrm{mL}$, $0.02 \mu \mathrm{g} / \mathrm{mL}, 17.47 \mu \mathrm{g} / \mathrm{mL}$ respectively.

Among the petroleum ether fractions of petroleum ether extract of $B$. javanica, $\mathrm{Fr} 1-8$ exhibited significant or moderate cytotoxicity against all the tested cell lines, except that Fr1-4 presented no inhibition to $\mathrm{NCl}-\mathrm{H} 460$ cell lines. Fr1 showed inconspicuous antitumor activity on the tested cell lines with the $\mathrm{IC}_{50}$ values all more than $50 \mu \mathrm{g} / \mathrm{mL}$, whereas, $\mathrm{Fr} 2$ displayed moderate cytotoxic activity on CNE, A549, MCF-7, HepG2 and KB-3-1 cell lines with $\mathrm{IC}_{50}$ values of 6.78 , 13.26, $16.83,22.73$ and $84.57 \mu \mathrm{g} / \mathrm{mL}$, separately. Fr3 \& 4 exposed a modest suppression in the proliferation of A549, MCF-7 and HepG2 cell lines with $\mathrm{IC}_{50}$ values ranging from 27.98 to $78.89 \mu \mathrm{g} / \mathrm{mL}$, $\mathrm{Fr} 3$ showed cytotoxic effect against KB-3-1 and CNE cell lines with the
$I_{50}$ values of 25.19 and $42.69 \mu \mathrm{g} / \mathrm{mL}$, while Fr4 had no cytotoxic activity against these two cell lines with $\mathrm{IC}_{50}$ values $>100 \mu \mathrm{g} / \mathrm{mL}$. Fr5 \& 7 displayed the same general tendencies of antitumor activity with highest $\mathrm{IC}_{50}$ values on A549 (6.04 and $7.21 \mu \mathrm{g} / \mathrm{mL}$, respectively), followed by CNE (9.24 and $11.59 \mu \mathrm{g} / \mathrm{mL}$, respectively), HepG2 (18.20 and $16.17 \mu \mathrm{g} / \mathrm{mL})$, MCF-7 $(18.26 \mu \mathrm{g} / \mathrm{mL}$ and $21.93 \mu \mathrm{g} / \mathrm{mL}), \mathrm{NCl}-$ $\mathrm{H} 460(33.77 \mu \mathrm{g} / \mathrm{mL}$ and $24.68 \mu \mathrm{g} / \mathrm{mL})$ and KB-3$1(30.05 \mu \mathrm{g} / \mathrm{mL}$ and $30.87 \mu \mathrm{g} / \mathrm{mL})$. Fr6 proved the antiproliferative rate against the tested cell lines with $\mathrm{IC}_{50}$ ranging from 8.34 to $33.87 \mu \mathrm{g} / \mathrm{mL}$. Fr8 exhibited a potent cytotoxicity against all the tested cell lines with $\mathrm{IC}_{50}$ values extending from 9.75 to $25.26 \mu \mathrm{g} / \mathrm{mL}$, of which were the highest values on MCF-7 $(13.57 \mu \mathrm{g} / \mathrm{mL})$.

\section{DISCUSSION}

It is well known that medicinal plants contain excellent antitumor compounds and they are ancient weapons in the defense against malignant neoplasms [1]. Antitumor agents destroy or inhibit the growth of tumors and over $50 \%$ of the currently used anti-cancer agents are derived from natural sources [4]. According to Geran et al., a crude extract having an $\mathrm{IC}_{50}$ value $\leq 20 \mu \mathrm{g} / \mathrm{mL}$ is considered active [17]. Under the concentration of $20 \mu \mathrm{g} / \mathrm{mL}$, the ethanol, petroleum ether, ethyl acetate and n-butyl alcohol extracts of $B$. javanica all exhibited a potent selected cytotoxicity against the tested cell lines, A549, CNE, MCF-7 and NCl-H460 in 
particular. Different classes of organic compounds, like quassinoids, alkaloids and triterpenoids, have been isolated and identified in the present research, and these compounds may be responsible for the cytotoxicity actions [12]. As a result of that, the ethyl acetate extract tend to be more active than the ethanol and petroleum ether extracts.

Brucea javanica oil extracted with petroleum ether from the fuits of $B$. javanica, is a complex mixture of fatty acids, which were reported to be cytotoxic active constituents [13]. The cytotoxic activity of petroleum ether fractions can be explained partly, by the high concentration of fatty acids and minor components such as sterides, pregnanones [18] and alkaloids. The large proportion of fatty acids might have contributed to the activities of the petroleum ether fractions against the tumor cell lines, because hexadecanoic acid and octadecenoic acid are known to possess cytotoxic activity [19]. However, Fr1 extract exhibited $I_{50}$ values almost more than $100 \mu \mathrm{g} / \mathrm{mL}$ on the tested cell lines, indicating that the esterification of fatty acids decrease the cytotoxicity. The decrease of esters and increase of pregnanones, sterids and alkaloids in Fr6, induced the improvement of cytotoxic capacity comparing to Fr5.

Despite the cytotoxic activities of petroleum ether fractions are lower than that of the positive control, the present results revealed their antitumor potential and further support the applications on clinical.

\section{CONCLUSION}

The present work has determined the chemical compositions of petroleum ether extract of $B$. javanica fruits by GC/MS analysis, and evaluated its cytotoxic activity. The results showed that the crude extracts and the petroleum ether fractions were significant or moderate active against the tested cell lines. Further studies should be undertaken next step to ascertain the phytochemical components and their bioactivities. This will be helpful to establish the foundation for clinical application of Brucea javanica oil.

\section{ACKNOWLEDGEMENT}

This work was jointly supported by grants from Chinese Academy of Sciences 100 Talents Program Endowment award to S.X.Q, the National and Guangdong Province Natural Science Foundation of China (No. 30973635, 10151065005000026), the Knowledge Innovation Program of the Chinese Academy of
Sciences (No. KSCX2-YW-R-217), National Science and Technology Major Project (No. 2009ZX09103-414), and Guangzhou Municipal Science and Technology Major Project (No. 2009A1-E011, 2010ul-E00531).

\section{REFERENCES}

1. Lee K-H. Discovery and Development of Natural ProductDerived Chemotherapeutic Agents Based on a Medicinal Chemistry Approach. J Nat Prod 2010; 73(3): 500-516.

2. Pan L, Chin YW, Chai HB, Ninh TN, Soejarto DD, Kinghorn $A D$. Bioactivity-guided isolation of cytotoxic constituents of Brucea javanica collected in Vietnam. Bioorg Med Chem 2009; 17(6): 2219-2224.

3. Chen H, Bai J, Fang ZF, Yu SS, Ma SG, Xu S, Li Y, Qu J, Ren JH, Li L, et al. Indole Alkaloids and Quassinoids from the Stems of Brucea mollis. J Nat Prod 2011; 74(11): 2438-2445.

4. Fiaschetti G, Grotzer MA, Shalaby T, Castelletti D, Arcaro A. Quassinoids: From Traditional Drugs to New Cancer Therapeutics. Curr Med Chem 2011; 18(3): 316-328.

5. Yu YN, Li X. Studies on the chemical constituents of Brucea javanica (L.) Merr. Yao Xue Xue Bao 1990; 25(5): 382-386.

6. Nakao R, Mizukami C, Subeki YK, Bawm S, Yamasaki M, Maede Y, Matsuura H, Nabeta K, Nonaka N, Oku Y, et al. Evaluation of Efficacy of Bruceine A, a Natural Quassinoid Compound Extracted from a Medicinal Plant, Brucea javanica, for Canine Babesiosis. J Vet Med Sci 2009; 71(1): 33-41.

7. Anderson MM, O'Neill MJ, Phillipson JD, Warhurst DC. In vitro cytotoxicity of a series of quassinoids from Brucea javanica fruits against $K B$ cells. Planta Med 1991; 57(1): 62-64.

8. Chen QJ, Ouyang MA, Tan QW, Zhang ZK, Wu ZJ, Lin QY. Constituents from the seeds of Brucea javanica with inhibitory activity of Tobacco mosaic virus. J Asian Nat Prod Res 2009; 11(6): 539-547.

9. Rahman S, Fukamiya N, Okano M, Tagahara K, Lee KH. Anti-tuberculosis activity of quassinoids. Chem Pharm Bull (Tokyo) 1997; 45(9): 1527-1529.

10. Sawangjaroen $N$, Sawangjaroen $K$. The effects of extracts from anti-diarrheic Thai medicinal plants on the in vitro growth of the intestinal protozoa parasite: Blastocystis hominis. J Ethnopharmacol 2005; 98(12): 67-72.

11. NoorShahida A, Wong TW, Choo CY. Hypoglycemic effect of quassinoids from Brucea javanica (L.) Merr (Simaroubaceae) seeds. J Ethnopharmacol 2009; 124(3): 586-591.

12. Liu JH, Jin HZ, Zhang WD, Yan SK, Shen YH. Chemical Constituents of Plants from the Genus Brucea. Chem Biodivers 2009; 6(1): 57-70.

13. Cui $Y$, Wu Z, Liu $X, N i R$, Zhu $X$, Ma L, Liu J. Preparation, safety, pharmacokinetics, and pharmacodynamics of liposomes containing Brucea javanica oil. AAPS PharmSciTech 2010; 11(2): 878884.

14. $Y u Y L, L u Y$, Tang $X$, Cui FD. Formulation, preparation and evaluation of an intravenous emulsion containing Brucea Javanica Oil and Coix Seed Oil for anti-tumor application. Bio Pharm Bull 2008; 31(4): 673-680.

15. Wu HW, Liu YQ, Yan ZJ, Wei SL, Ye JQ. A Gas Chromatography-Mass Spectrometry Analysis of the Essential Oils from Brucea javanica Extracted with Different Methods. Fine Chemicals 2011; 28(7): 668.

16. Mosmann T. Rapid colorimetric assay for cellular growth and survival: application to proliferation and cytotoxicity assays. J Immunol Methods 1983; 65(12): 55-63.

Trop J Pharm Res, October 2013;12 (5): 741 
17. Geran R. Protocols for screening chemical agents and natural products against animal tumors and other biological systems. Cancer Chemother Rep 1972; 3: 51-61.

18. Chen YY, Pan QD, Li DP, Liu JL, Wen YX, Huang YL, Lu FL. New Pregnane Glycosides from Brucea javanica and Their Antifeedant Activity. Chem Biodivers 2011; 8(3): 460-466.
19. Tronstad KJ, Bruserud O, Berge K, Berge RK. Antiproliferative effects of a non-beta-oxidizable fatty acid, tetradecylthioacetic acid, in native human acute myelogenous leukemia blast cultures. Leukemia 2002; 16(11): 2292-2301. 